\title{
Toplumsal Gerçekliği İnşa Eden İllüzyon: Meşruiyet
}

\section{Legitimacy: Illusion which is Constructing the Social Reality}

\begin{abstract}
Mehmet Fatih GÜLOĞLU *
Öz: Sosyal bilim literatüründe meşruiyet kavramı, insan eylemleri ve bu eylemlerin kurumsallaşması için kurucu bir zemin olarak değerlendirilmektedir. Meşruiyet, literatürdeki tartışmalarda her zaman 'elde var' başka bir deyişle a priori olarak kabul edilmiştir. Bu anlam, meşruiyetin halihazırdaki tüm eylem kalıpları için önceden kabul edilmiş ve soruşturulmayan transandant bir öğe olarak görülmesine yol açmıştır. Ancak toplumsal gerçekliğin nasıl oluştuğu üzerine yapılan tartışmalar, meşruiyet kavramını müphemleştirmektedir. Bu müphemlik kavramın 'kendinden-referanslı' olması nedeniyledir. Makale, meşruiyetin toplumsal gerçekliğin oluşumunda ve onun anlamlandırılmasında oynadığı rolü soruşturmaktadır. Makalede, meşruiyetin toplumsal gerçekliği inşa eden bir güç olduğu ancak bu inşa sürecinin bütünüyle kurgusal olduğu öne sürülmektedir. Başka bir deyişle meşruiyet, bataklığa bıraktığı anlamlılık kayasının dibe çöküşüne kadar eylemler için bir dayanak üretmektedir. Makalede Ricouer'ün hermeneutik yöntemini kullanılmıştır. İlk olarak, analitik düşünme kısmında 'meşruiyet' ve 'toplumsal gerçeklik' kavramlarının her bir bileşeni ayrıntılı bir şekilde analiz edilmiştir. Böylece iki kavram arasındaki diyalektiğe giden yol açılmıştır. İkinci olarak, diyalektik düşünmeyle toplumsal gerçeklik ve meşruiyet arasındaki ilişkinin mahiyeti ve döngüselliği açığa çıkarılmıştır. Sonuç olarak, toplumsal gerçekliğin kurucu zemini olan ve toplumsal gerçeklik tarafından yeniden üretilen bir kavram olan meşruiyetin bizatihi kendisinin müphemliği nedeniyle toplumsal gerçekliğin haklılandırılmasının 'süreklileştirildiği' belirtilmiştir.
\end{abstract}

Anahtar sözcükler: Meşruiyet, Toplumsal Gerçeklik, Hermeneutik, Haklılandırma

Abstract: In social science literature, the concept of legitimacy is considered as a foundation ground for human actions and the institutionalization of these actions. The concept of legitimacy has always been taken for granted in the literature. This has led legitimacy to be seen as a transcendent unit that has been previously accepted for all the current patterns of action and cannot be investigated. However, the debates on how social reality is formed make the concept of legitimacy more ambiguous because the concept is self-referred. This article investigates the role of legitimacy in the formation and meaning of social reality. It is claimed that legitimacy has a power that constructs a social reality, but this construction process is entirely fictional or arbitrary. In other words, legitimacy provides a basis for actions until the collapse of the rock of significance that it left to the swamp. In this article, the hermeneutic method of Ricouer was used to investigate the claims. First, in the section of analytical thinking, each component of the concepts of legitimacy and social reality is analysed in detail. Thus the path to the dialectic between the two concepts is opened. Secondly, in the dialectical thinking part, the nature and cyclicality of the relationship between social reality and legitimacy are shown. As a result, it has been stated that legitimacy as the constituent ground of social reality and as a concept reproduced by social reality has made the justification of social reality continue due to the ambiguity of the concept itself.

Keywords: Legitimacy, Social Reality, Hermeneutics, Justification

\footnotetext{
* Dr. Öğr. Üyesi, Kilis 7 Aralık Üniversitesi, Fen-Edebiyat Fakültesi, Sosyoloji Bölümü, Kilis. mfguloglu@gmail.com, https://orcid.org/0000-0001-9136-4683
} 
Meşruiyet kavramına, çoğunlukla hukuk ve siyaset literatüründe atıflarda bulunulmaktadır. Bu atıfların çoğu iktidar ve onun faaliyetleri eksenindedir (Weber 1995; Bauman 2000; Çetin 2003; Rawls 2007; Schmitt 2016; Heywood 2017). Sosyoloji literatüründe ise kavram farklı düzeylerde tartışılmaktadır: Örneğin Giddens (2005) için meşruiyet, yapılaşmanın ana unsuru iken; Berger ve Luckmann (2008) için gerçekliğin toplumsal olarak inşa edilmesini sağlayan öğedir. Bu tanımlamalara göre kavram, kurumsal düzeyde bir anlamlandırma aracı iken; ilişkisel düzeyde ise aktörün karar alıcı pozisyonuna yani failliğine gönderme yapmaktadır. Meşruiyete yönelik bu yaklaşımlar, kavramın gündelik hayatın idamesini şekillendirmesi üzerindeki rolünün önemini göstermektedir. Bir başka deyişle meşruiyet, sosyal sistemin kendini haklılandırma çabasıdır (Habermas 1988). Kendinden-referanslı bir kavram olan meşruiyet, bataklığa bıraktığı anlamlılık kayasının dibe çöküşüne kadar eylemler için bir dayanak üretir. $\mathrm{Bu}$ iddia, toplumsal gerçekliğin haklılandırılmasının sürekliliğini göstermektedir. Bu çabanın sürekliliği, meşruiyet ile toplumsal gerçeklik arasındaki döngüsel ilişkinin birbirlerini yeniden üretmesiyle sağlanmaktadır.

Metinde şu sorular araştırılmıştır: Kendinden referanslı olan meşruiyet, nasıl oluyor da toplumsal gerçeklik için meşru bir zemin sunabilmektedir? Meşruiyetin toplumsal gerçekliğin inşası için sunmuş olduğu bu zemin nasıl kabul edilmekte ve olumlanmaktadır? Bunun dayanakları nelerdir? Bu sorular ekseninde çalışmada toplumsal gerçekliğin meşruiyetinin 'döngüselliği’ ortaya konulmaktadır. Çalışma kapsamında bu döngüsellik şöyle ifade edilmiştir: Meşruiyetin geçeklik kazandırdığı söylem gündelik hayatta mücbir hale gelir. Mücbirleşen gerçeklik, hakikat olduğunu iddia ederek toplumsal gerçekliği yeniden üretir. Fakat meşruiyet tarafından hakikat payesi verilen ve haklılandırılan toplumsal gerçeklik, aynı şekilde meşrulaştırıcı prosedürlerin de yeniden üretilmesini sağlamaktadır. Böylece meşruiyetle toplumsal gerçeklik arasındaki ilişki döngüsel bir karakter kazanır.

\section{Hakkaniyetli Bir Soruşturmanın İmkanı}

Makale şu iki savı aynı anda ortaya koymaktadır: Gerçeklik toplumsal olarak inşa edilir; bizim dışımızda bir gerçeklik vardır (Searle 2005; Berger \& Luckmann 2008). Bu iki sav, toplumsal inşacı bir perspektif ile dışsal gerçekçi perspektifin toplumsal olguların varlık tarzlarını anlamak için ortaklaşa çalışabileceğini iddia eder. $\mathrm{Bu}$ minvalde bu iki varsayım ile meşruiyetin kendinden-referanslı oluşu arasındaki ilişki çalışmanın odak noktasını oluşturmaktadır. Bu odaklanma sürecinde yazar, radikal şüpheyi kendisine rehber edinerek hakkaniyetli bir çalışma yürüttüğünü düşünmektedir. Bourdieu ve Wacquant'ın $(2003,242)$ için radikal şüphe, "sosyolog, toplumsal bir varlık olmasının, dolayısıyla yapılarını içselleştirdiği toplumsal dünyada kendini sudaki balık gibi hissetmesine yol açacak şekilde toplumsallaşmasının beraberinde getirdiği varsayımları paranteze almak için gerekli" ve "düşünümsel yönelimli" bir tutumdur. Yazar böyle bir tutumu kendisine rehber edinmeye çalışmışır.

Metnin savları Ricoeur'ün (2006) dönüşlü düşünce olarak adlandırdığı hermeneutik yöntemi kullanılarak soruşturulmuştur. Ricoeur'ün hermeneutik yaklaşımı, soyut düşüncenin somutlaştırılması amacını taşır. Dolayısıyla Ricoeur'ün yaklaşımının somut olanı öncelediğini söylemek yanlış olmaz. Yönteminin iki adımı vardır: Analitik ve diyalektik düşünme. Analitik düşünmeyle her iki kavramın derin anlamlarına ulaşılmaya çalışılıp her iki kavramın hangi ufuklarda kesiştikleri veya hangi bağlamlarda ayrıştıkları belirlenmiştir. Toplumsal gerçeklik ve meşruiyet kavramları ayrıntılı bir analize tabi tutulmuş ve tarihsellikleri inşa edilmiştir. Diyalektik düşünme kısmında ise iki kavram arasındaki ilişki ve aralarındaki diyalektiğin nasıl bir dolayım ürettiği belirtilmiştir. Bu ikili düşünme yöntemi eklektik bir girişim değil, aksine kavramların yeniden yorumu için bir firsattır. $\mathrm{Bu}$ yöntemin seçilmesinde, tartışmanın iki varsayımının ancak bu şekilde somutlaştırılabileceği düşüncesi önemli bir rol oynamıştır. Başka bir deyişle diyalektik bir ilişki ancak diyalektik bir yöntem ile ancak açık bir şekilde aşikar kılınabilir. 
Böylece toplumsal geçekliğin dayanakları önerilebilmiş, yani toplumsal gerçekliğin meşrulaştırılmasının gerekçeleri ortaya konulmuştur.

\section{Analitik Düşünme}

Analitik düşünme edimiyle bir eleştiri olmaksızın kavramların içerimleri analiz edilmiştir. Böylelikle iki kavram arasındaki soyut ilişkinin somutlaştırılmasının ilk adımı atılmıştır. Diyalektiğe giden patika olan bu düşünme edimi altında ilk olarak gerçeklik kavramı daha sonra da meşruiyet kavramı ele alınmıştır.

\subsection{Gerçeklik}

Gerçeklik üzerine felsefi tartı̧̧malar iki bağlamda (gerçekçilik ve gerçekçilik karşıtı) yürütülmektedir: İlki insan bilincinden bağımsız bir şekilde 'orada olan'ı işaret ederken; ikincisi olguların insanın bilinci aracılığıyla inşa edildiğine işaret eder. Başka bir deyişle gerçeklik, idealistlerle realistler arasındaki karşıtlık ekseninde tanımlanmış olup insanın tasarımlarının oluşturduğu bir gerçeklik anlayışıyla bağımsız bir dışsal gerçekliğin varlığının kabulü şeklinde çatallanır (Marshall 1999, 266). Gerçekçilik ve idealizm olarak ifade edilecek bu iki yaklaşım gerçekliğe yönelik tanımlamaları şekillendirmektedir. Gerçekçilerin, gerçekliğe yaklaşımı özetle şöyledir: "Gerçekçilik kavramı altında iki farklı anlam toplanmaktadır. 1: Aklın dışında bir dünya mevcuttur ve 2- o, dünyanın bilgisini edinebilir" (Harman 2015, 126). Bununla beraber gerçekçilik yaklaşımları da birçok farklı nüansları içinde barındırmaktadır. $\mathrm{Bu}$ makale gerçekçiliğin ya da idealizmin temel argümanlarını tartışmaya açmamakla birlikte, öne sürmüş olduğu iki tezin uyumlu çalışmasını göstermek zorundadır. Bu konuda her ne kadar günümüz dünyasında gerçekçilerin idealizme ek olarak inşacılarla da çatışma içinde olduğunu belirtse de Ferraris'in $(2014,65)$ gerçekçilik ile toplumsal inşacılık arasındaki "kalıcı bir barış" dediği bağlam cesaret vericidir. Bu bağlamı şu önermelerle dile getirir:

\section{“1) Doğal nesneler epistemolojiden bă̆ımsızdır. 2- Deneyim bilimden bă̆ımsızdır. 3- Sosyal nesneler, öznel olmaksızın, epistemolojiye bağım- lıdırlar. 4- 'Kavramsiz sevgiler kördür' yargisı öncelikle sosyal nesne- lere uygulanır. 5- Gerçekçi sezgi ve inşacı içgörü bu nedenle kendi uygulama alanlarında eşit meşruiyete sahiptir".}

Searle'nin niyetlilik önerisi yerine belgeleme; kaba ve kurumsal olgular yerine de doğal ve sosyal nesneler kavramsallaştırmalarını öneren Ferraris'in bu 'kalıcı barış önerisi' çalışmanın gerçekliğe bakışındaki öne sürdüğü iki savın ana dayanağını teşkil etmektedir. Bu başlık altında, kavramın meşruiyetle olan ilişkisini kurabilmek için ontoloji ve epistemoloji arasındaki ayrışıklı̆g 1 koruyarak fakat aynı zamanda uzlaştırarak aşma teşebbüsünde bulunulmuştur. Başka bir deyişle, gerçekliğin meşruiyet ile bağını kurabilmek için ontoloji ve epistemoloji arasındaki ayrım Hegelyen terminoloji ile 'aufgehoben' kelimesi yani 'ortadan kaldırılmış ve aynı zamanda korunmuş ve korunarak da yüceltişmiş’ çerçevesinde düşünülmüştür (Hegel 1996, 94). Ancak Almanca literatürde geçek kavramı iki kelime ile birlikte düşünüldüğü de belirtilmelidir: 'Wirklich: gerçek, hakikat ya da edimsellik; Wahr: gerçeklik, doğruluk (Hegel 1996). Dolayısıyla gerçekliğin somut dışsallığı ile tasarımlanmış olgusallığı arasındaki ayrım ontoloji ve epistemoloji arasındaki kopuşun ama aynı zamanda uzlaşı fırsatının da bir göstergesidir.

Bahsedilen teşebbüse, gerçekliğin bilgisine dolaysızlık içinde ulaşmanın imkansız olduğu ancak gerçekliği bilenebilir kılan öğelerin ise dolaysız olduğu dile getirilerek başlanmıştır. $\mathrm{Bu}$ minvalde iki iddia öne sürülmüştür: 1- İnsan, gerçekliği dolayslz bir şekilde bilemez; 2- Innsan, gerçekliği veren melekelere dolaysı bir şekilde sahiptir. Bu iki önermenin birlikteliği, gündelik yaşamın hem rutinini hem de metafiziksel kısımlarını bir arada görmeyi sağlar. "Öyleyse, ontolojide daima bir epistemolojik kalıntı ve epistemolojide bir ontolojik bir tortu vardır" 
(Ferraris 2014, 33). Özellikle rüyaların sahteliği nedeniyle imgeleme bütünüyle güvenilemeyeceği diğer yandan da algıların yanlış yönlendiriciliği nedeniyle dış gerçekliğin bütünüyle edinilemeyecek olması düşünürleri gerçeklik hakkında farklı yorumlara sevk eder. Sosyal ya da kurumsal gerçeklik ile kaba ya da dış gerçeklik böyle bir ontoloji ile epistemoloji arasındaki gerilimde karşımıza çıkmaktadır. Sosyal gerçeklik ya da makalede ifade edilen toplumsal gerçeklik Ricoeur'ün hermeneutik yaklaşımının rehberliğinde hem inşacıllı̆ı̆ hem de gerçekçiliğin somutlaşabileceği bir zemin için firsat sunar. Nitekim Ferraris $(2013,126)$, ideal, sosyal ve doğal nesneler arasında ayrım yapar. Sosyal nesnelerin sadece onun farkında varıldığında var olduğunu ifade eder. Bu konuda görünmez mürekkeple yapılan ya da belgenin olmadığı bir dünyada yapılan evliliği örnek gösterir. Böyle bir evliliğin geçerliliğinin olmadığını söyler. Dolayısıyla sosyal nesnelerin varlığının 'hatırlamayla' ilgili olduğunu israrla belirtir. Dolayısıyla gerçekçilik ile idealist yaklaşımın toplumsal gerçeklik hakkında uzlaşabileceği bir alan kurulur.

Gerçekçiler arasında gerçekliği ele alma tarzlarında farklılıklar olmakla birlikte Popper'ın günümüzdeki güçlü temsilcilerinden olan Chalmers $(2010,183)$, realizmi "dünyanın gerçekte nasıl olduğunun daha iyi veya daha kötü tanımları"nda bulunan teori olarak ifade eder. Bu eksende Chalmers $(2010,180)$, realizmi üç ana başlık altında sınıflamıştır:

"Gerçekçilik, 1- olguların veya gerçekliğin kendisiyle zihni meşguliyet; idealizmin, spekülasyonun ve hissiyatın etkisi altında kalmayan nesnel prosedür; nesnel/objektif düşünme ve eyleme tarzl; pratik ve görülebilir olmayan reddetme eğilimi. 2- Felsefede, tümellerin, zihinden bağımsız bir gerçekliğe sahip bulunduklarını savunan doktrin: Bir genel veya soyut terimin adlandırdı̆̆ şeyin, bağımsız ve bölünemez bir gerçekliğe veya öze sahip olduğu anlayışı: (a) tümellerin nesnelerden önce var olduklarını savunan doktrin: Platonik Realizm, (b) tümellerin nesneler içinde var olduklarını öne süren doktrin: Aristotelesçi Realizm. (3) duyu algilarının nesnelerinin veya genelde alginin nesnelerinin, kendi başlarina reel olduklarl ve bilme eyleminden veya zihinle ilişkilerinden bağımsız olarak mevcut bulunduklarını öne süren felsefi anlayış: Epistemolojik Realizm. Bilen özneden bağımsız olarak var olan gerçekler evreninin bulunduğunu ve bu gerçekler evreninin bilgisine idrak veya düşünme yoluyla erişebileceğimizi öne süren doktrin. Idealizmin zıddl"”.

$\mathrm{Bu}$ üç tasvir temel tartışma alanlarını özetlemektedir. Pasaj, gerçekliğin, idealizmin karşıtı olduğunu ve nesnel bilginin insandan bağımsız bir varoluşa sahip olduğunu belirtmektedir. Bu tanımlamanın bir benzeri Bhaskar $(2015,37)$ tarafından yapılmıştır: "Realizm, bilimsel incelemenin nihai nesnelerinin bilim insanlarından ve onların faaliyetlerinden oldukça bağımsız bir şekilde var olduklarının ve hareket ettiklerinin teorisidir". Bhaskar (2017), insandan bağımsız bir dünya varsayılmadığında bilimsel bilginin mümkün olamayacağını öne sürer. Aynı zamanda dünyanın ancak kavramlarla açıklanabileceğini öne sürerek de Kant'ın yolundan gidip transandantal realizm dediği üçüncü bir yol açar (Marshall 1999, 266). Ancak Kant, Hacking'e (2016, 125) göre transandantal idealist ve empirik gerçekçidir. Kant için transandantal gerçekçilik, "gerçekten dışarıda nesneler vardır, onların varlığını ve niteliklerini duyusal deneyimlerden çıkarsarız" cümlesiyle özetlenebilir. Bunun gerekçesi ise maddi olayların hem zaman hem de uzayda cereyan ederken zihinsel olayların sadece zamanda cereyan ettikleri düşüncesidir.

Gerçeklik, insanın ampirik olarak deneyimlediği ve teorik olarak tasarladığı olmak üzere ikili bir şekilde düşünülür. Örneğin 'masanın sertliği', dokunma deneyiminin ampirik bir sonucu 
olup dışsal bir gerçekliğe işaret ederken; 'sert masa kalitelidir' ifadesinin karşılık geldiği olgusal durum düşünsel bir gerçekliği belirtir. Ancak gerçekliğe dönük yaklaşımlardaki bu farklanma aslında diyalektik birlikteliğin izlerine işaret etmektedir. Çünkü nesnenin episteme düzeyinde bilinmesi bir 'temas' sayesinde gerçekleşir; ve bu temas sayesinde varllk tecrübe edilir: "Gerçeklik başkasıyla olan ilişkide yatmaktadır" (Ricouer 2006, 239). Nitekim Schutz (1962, 208) gerçeğin kökenini öznel olarak yorumlamakta ve "gerçeklik, duygusal ve aktif yaşamımızla ilişki kurmak anlamına gelir" demektedir. Dolayısıyla gerçeklik, bir yanıyla dış dünyanın algılanmasına dayalı iken diğer yandan da bu dünya üzerine düşünmeyle ilişkilidir. Gerçeklik, aynı zamanda, deneysel olanla aşkın olanın 'burada' bilinebilir olmasının imkanıdır. Gerçeklik, içinde bulunduğumuz ortamın bizatihi kendisidir. Ancak gerçeklik, anlam vermeyle birlikte sorunsallaşır ve içinde bulunduğumuz 'bura' yorumsal bir dünyadır (Giddens 2005). Özellikle sosyolojik olarak gerçekliğin toplumsal etkinlikler ya da ilişkiler sayesinde inşa edildiği düşünüldüğünde makale, Searle'nin (2005), Berger ve Luckmann'ın (2008) ve Giddens'in (2005) çalışmalarını referans almıştır. Böylelikle hem dışsal gerçekliğin hem de kurumsal/toplumsal gerçekliğin birlikte işlediği bütünsel bir dünya tasavvuru mümkün hale gelmektedir.

Searle, gerçekliği birbiri için varoluşsal olarak zorunlu olan kurumsal ve kaba olgular olarak adlandırdığı ikili bir düzeyde açıklar. Bu ayrım sayesinde Searle, hem toplumsal dünyanın üzerine inşa edildiği zemini hem de bu dünyayı anlamayı sağlayacak argümanları geliştirir.

"Kurumsal olgular, var olmak için insan kurumlarına gerek duyarlar.
Kaba olgular ise, var olabilmek için insan kurumlarına ihtiyaç
duymazlar. Bir kaba olguyu ifade etmek için elbette bir kurum olan dile
ihtiyaç duyarlz; ancak, ifade edilmis bir olguyla onun ifadesini
birbirinden aytrmak gerekir" (Searle 2005, 16).

Kaba olgularla Searle, dışımızda bir gerçekliğin varlığını olumlar. Nitekim Searle $(2005,188)$, "dünya bizim onu temsilimizden bağımsız olarak vardır. Bunun adı dış gerçekliktir" demektedir. Kurumsal olgular ise inşa edilen ve dilin kullanımını, temsillerin üretimini içeren bir dünya tasavvurunu gerektirmektedir. Kurumsal olguyu, kolektif niyetliliğin gündeme getirilmesi olarak ifade etmektedir (Searle 2005, 46). Kurumsal bir olgunun, yani toplumsal gerçekliğin, inşa edilmesi için üç kavramsallaştırmaya müracaat eder: "İşlev yükleme, kolektif niyetlilik ve düzenleyici ve kurucu kurallar arasındaki ayrım" (Searle 2005, 49). İşlev yükleme, kişinin nesnelere yapmış olduğu bir atfı içerir. Bu gönderme "asla içkin değildir; işlevler kullanıcıların ve gözlemcilerin ilgilerine bağlı olarak atfedilir” (Searle 2005, 36). Ancak Searle'nin kolektif niyetlilik argümanına karşı Ferraris $(2014,60)$ belgeleme kuralını önerir. Başka bir deyişle gerçekçiler arasında, gerçekliğin ne olduğuna dair yoğun tartışmalar varlığını devam ettirmektedir.

Gerçeklik, bir yanıyla dışsal dünyaya diğer yanıyla da 'dile getirilebilen', 'temsillerle örülü' dünyaya atıfta bulunur. Örneğin ünlü filozof Hacking, gerçekliğin bilinmesinin 'müdahale' ile birlikte olduğunu öne sürer. Nitekim atom altı parçacıklarla ilgili yorumlamada bulunduğu bir pasajında kendisini şöyle ifade eder: "Benim ilgilendiğim kadarıyla onları püskürtebiliyorsan gerçektirler” (Hacking 2016, 42). Her ne kadar Kartezyen felsefenin ikili özcülüğünün (ruhsal öz ve mekânsal öz) modern dünya için kısıtlayıcı olduğunu düşünse de -Marxgil bir duruşlagerçekliği ya Kartezyen dünyanın dilinin içinde ifade eder (püskürtebiliyorsam gerçektir) ya da idealizme yaklaşmaktadır ki püskürtme kavramının anlamı (meaning) yoğun bir Platonik mirasa atıfta bulunur. Her iki yöndeki duruşu da bu çalışma için önem arz eder çünkü çalışma; inşacılık, yapısalcılık ve dışsal gerçekçiliğin birlikteliğini meşruiyet kavramının kaygan zemininde buluşturmaya çalışmaktadır. Gerçekliğin bu ikili içerimi bir yandan dolaysız bilinemezliğine diğer yandan da dille ifade edilebileceğine işaret eder. Böyle bir durumu Searle kurumsal gerçeklikle açıklar. Searle, kaba gerçekliğin toplumsal gerçeklik haline getirilebileceğini belirtir. Örneğin mermer bir taş birçok işlev ve statü yüklenerek kurumsal bir 
olgu (sanat) haline getirilebilir. Kaba bir olgu statü yüklenerek toplumsallaştırılır (Searle 2015).

Kurumsal bir olgunun kaba bir olgudan ayırt edici niteliği olarak Searle, -Wittgenstein'a atıfla-, 'kural'a işaret eder: "Nesnelerin bir değişim aracı olma işlevini sürdürebilmeleri bir uylaşım meselesi değil kurallar meselesidir (...) gerçek kurumsal olguların mevcut olup olmadıklarını anlamanın yolu, kuralları açık seçik bir şekilde yasalaştırabilmekten geçer" (Searle 2005, 72-116). Dolayısıyla dilbilimcilerin dildeki keyfiliğe işaret etmek için kullandıkları 'uzlaşım' kavramsallaştırması yerini düzenleyici ve kurucu kurallara bırakmaktadır. Bu bağlamda Searle, Berger ve Luckmann'ın yaklaşımdan (içselleştirme, dışsallaştırma ve nesnelleştirme) farklılaşarak toplumsal gerçeklik konusunda oyun teorisine yakın bir pozisyon almaktadır. Ona göre dil, "kurumsal gerçekliğin kurucu öğesidir" (Searle 2005, 83). Ancak dil hakkındaki düşünceleriyle Berger ve Luckmann $(2008$, 58) ile benzeşmektedir: "Dil, bütün bu aşkınlıkların bir sonucu olarak mekânsal, zamansal ve sosyal bakımdan 'burada ve şimdi' olmayan çeşitli nesneleri 'burada kılmaya' muktedirdir'. Her ne kadar dile yaklaşımları konusunda benzeştikleri söylenebilse de hasım teorisyenler oldukları da göz ardı edilmemelidir. Dolayısıyla toplumsal gerçeklik dil üzerinden 'inşa' olduğundan, toplumsal gerçekliğin meşruiyeti bütünüyle dilin keyfiliğine kalmıştır. "Dil, sınırlı anlam alanlarına aile tecrübelere atıfta bulunabilir ve farklı gerçeklik alanlarının birinden diğerine atlayıp geçebilir" (Berger \& Luckmann 2008, 59). Bu bağlamda Berger ve Luckmann perspektifinden toplumsal gerçeklik dil aracılığıyla inşa edilir. Bu konuda Searle'nin yaklaşımının ise yapısalcılığa daha yakın durduğunu söylemek hata olmaz. Ancak bu ilişki bir yandan keyfilik ve uzlaşı bir yandan da düzenleyici ve kurucu kuralların varlığı ile açıklanmaktadır.

Dilin inşa ettiği/dilde inşa edilen toplumsal gerçeklik, kabul edilmiş bir gerçekliktir. Kabul etme işlemi gerçekliğin nasıl meşrulaştırıldığıyla alakalıdır. Gerçek olan bir şeyin kabulü ya da kabul olunan şeyin gerçekliği onun meşruiyetiyle doğru orantılıdır. "Kurumsal bir gerçekliğin yaratılmasında ve inşa edilmesinde tek bir mantıksal işlem söz konusudur ve o da şudur: Kolektif olarak biz, (S güce sahiptir (S, A'yı yapar))'ı kabul ederiz, değerlendiririz, tanırız ve benimseriz vb." (Searle 2005, 143). Ferraris $(2014,60)$ ise Searle'nin bu yaklaşımına müdahalede bulunur:

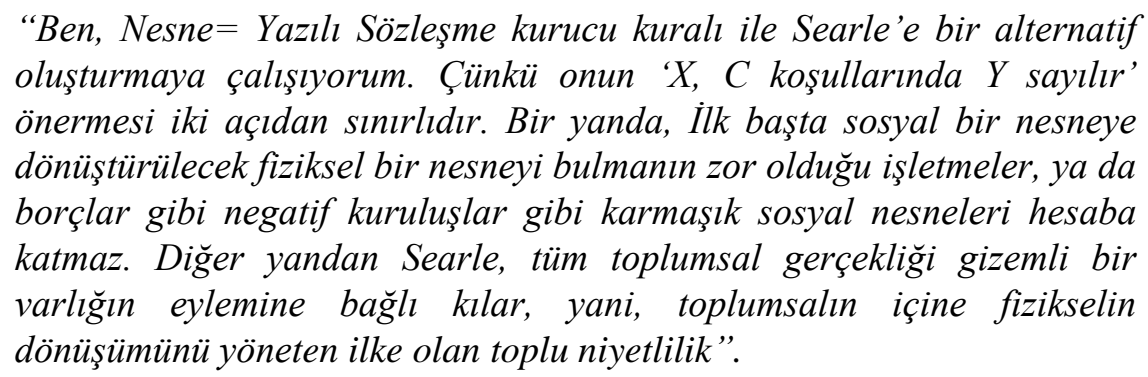

Tüm bunlar totalde her ne kadar anti-gerçekçi bir tutum gibi görünse de onamanın/rızanın önemine işaret eder. Öyle ki bu anlayışta gerçeklik onanmış bir şeye dönüşür. Onama, gerçek olan üzerine yapılan ittifaka katılmak demektir. Dolayısıyla toplumsal gerçeklik varsayılmış bir gerçekliktir.

Gerçekliğin inşa edilen bir olgu olarak ele alınması başka bir deyişle tasarım olarak dünya fikri mantığın toplumsallığını gündeme getirir. Durkheim $(2009,34)$ bu kanatta yer alır. "Aklın kategorilerinin sosyal kaynaklı oldukları kabul edilecek olursa, inancımıza göre bu birbirine zıt güçlüklerden kurtulmayı sağlayacak yeni bir durum mümkün hale gelecektir". Aklın kategorilerinin toplum kaynaklı olduğunu öne sürmek onun toplumsal etkinlikler sonucu inşa edildiğini ifade etmektir. Bu hamle, bir eylemin icrası için mantığın kullanılması gerektiği fikri yerinden eder. Başka bir deyişle bilmek için artık mantığa gerek duyulmaz (Woolgar 1999, 65). Toplumsal yapılar, eylemler için pratik setlerini içerisinde barındırırlar. "Durkheim, toplumsal 
gerçeklerin 'bizi kendi rolümüzü oynamaya zorlayan kalıplar' gibi olduklarını söyler” (Trigg 2005, 77). Dolayısıyla toplumsal olanın olguya önceliği nedeniyle gerçeklik ancak toplumsal alanda açığa çıkar. Elbette gerçekçiler için dışsal bir gerçekliğin varlığı düşüncesi kurumsal olgular ya da sosyal nesnelerin ontolojik varlık tarzlarına yaklaşımı farklılaştırır. "Bazı varlıkların öznel bir var oluş tarzı vardır. Bazılarının da nesnel bir var oluş tarzı vardır" (Searle 2016, 44). Searle epistemolojik olan ile ontolojik olan arasındaki ayrımı belirginleștirmek gayretindedir: "Nesnel-öznel ayrımının epistemik anlamıyla ontolojik anlamını ayırt etmeliyiz" (Searle 2016, 43). Ancak Searle öznel ve nesnel var oluş tarzı ayrımıyla aslında Berger ve Luckmann'ın inşacı yaklaşımlarıyla benzerlik teşkil etmektedir. İnşacıllk, özetle "gerçekliğe dair kendi uyarlamalarımızı bir kültür ya da toplum olarak kendi aramızda inşa ettiğimiz söylenebilir" (Burr 2012, 6). Aslında bu benzerlik kaçınılmazdır. "Naif gerçekçilik, gerçekliğin zihin dışında olduğunu düşünür ve bunu bilebiliriz diye düşünürken, nesne-yönelimli (objectoriented) gerçekçilik gerçekliğin zihin dışında olduğunu ve onu bilemeyeceğimizi iddia eder" (Harman 2016, 17). Dolayısıyla gerçekçi yaklaşım kendi içinde oldukça farklı yaklaşımlar barındırırken ontoloji ile epistemoloji arasındaki ayrımı çok keskin çizmek düşünmeyi kısırlaştırmaktır. Dolayısıyla gerçekliğin toplumsal olarak inşasını ifade etmek kaba olgulardan ziyade kurumsal olgulara yönelmek anlamına gelip gerçekliği felsefenin konusu olmaktan sosyolojinin konusu haline getirir. Nitekim Berger ve Luckmann'ın $(2008,3)$ "gerçeklik, sosyal olarak inşa edilmiştir" demeleri bu anlamda önem arz etmektedir.

Gerçeklik tartışmasının felsefeden sosyolojinin konusu haline gelmesinde fenomenolojinin önemli katkısı bulunmaktadır. 'Tecrübe' kavramı ve 'önyargıların paranteze alınması'yla gerçekliğin katmanlı yapısına giden yol aralanmıştır. Bu katmanlı yapı bilincin yönelmesini içerir. Bu konuda Searle'nin 'tekçi dünya görüşü' önem arz etmektedir. "Bırakın zihinsel, fiziksel ve kültürel gibi üç dünyada, fiziksel ve zihinsel gibi iki dünyada yaşadığımıza bile değil, tek bir dünyada yaşadığımıza inanıyorum" (Searle 2015, 15). Bu bu tekçi dünya görüşü cümlesinde de zikredilen dünyaları dışlamasıyla ya da bir tür materyalizme indirgemesiyle (bilinci mide gibi ele almak) sorunsallaşmıştır. Gerçeğin katmanlı yapısı diğer yandan da uzam ve zaman kategorilerinde işleyen varlıklarla teması gerektirir. "Gündelik hayatı hem uzamsal hem de zamansal olarak farklı yakınlık ve uzaklık derecelerinde tecrübe ederim" (Berger \& Luckmann 2008, 35). Dolayısıyla gerçeklik bu zaman ve uzam kesişimlerine yüklenen anlamlardır. Bu anlamların keşfi ise 'Ben' aracılığıyladır. 'Ben' aracılı̆̆ıyla uzay ve zaman kategorileriyle birlikte dış gerçekliği keşfeder. Bu bağlamda 'ben', tecrübenin anlamlandırılması ve yorumlanmasının da ana uğrağıdır. "Tecrübe bize, gerçekliği tanımayı öğretir. Bütün bu tecrübeden uygun tarzda elde edilen şey, bu durumda, olanı bilmektir" (Wachterhauser 2002, 146). Tanınan gerçeklik dolaysızlık içinde değil de insanın dolaysız olarak sahip olduğu melekeler aracılığıyla tecrübe edilmektedir. Başka bir deyişle gerçeklik, dolaysız olarak sahip olunan 'ben" in melekeleriyle bilinir. "İnsan bilimlerinde, 'bildiğimiz şey, nihai belirlemede, kendimizizdir. İnsan bilimlerinde bilgi daima kendi/ben-bilgisi hakkında bir şeydir" (Wachterhauser 2002, 130). Hacking $(2016,126)$, Kant'n fenomen ve numen ayrımından hareketle "bilgimiz, fenomenlerin bilgisidir ve nesnelerimiz fenomenler dünyasında vardırlar" demektedir. Ancak bu 'ben'in diğer 'ben'lerle ortak paylaştığ 1 birçok şey bulunmaktadır. 'Ben'in bildiği gerçeklik, Berger ve Luckmann'ın ifadesiyle, rölativite ejdarhasını doğurduğu söylenemez. Nitekim Hacking hiçbir şekilde bir rölativist olarak görülemez.

"Gerçek bir rölativist her zaman 'dünya' gibi şeylere ait fikirlerin zaten teorik olduğunu, bu fikirlerin ancak birisinin savunduğu inançlar çerçevesinde anlaşılabileceğini söyler. Bu fikirler, sadece birinin sahip olduğu inançlar bağlamında anlaşılabilir. 'Gerçeklik' bir grubun gerçek olduğuna inandiğ şeyden ayrı bir anlama sahip değildir. Bütün bakış 
açılarından bağımsız, tam olarak nesnel bir dünya kavramı hiçbir işe yaramaz" (Trigg 2005, 35).

Böyle bir rölativist tutum, öznel ve nesnel gerçeklik ya da kaba ve kurumsal olgular ayrımını benimsemenin sonucu değildir. Belirtildiği gibi gündelik hayat nesnel gerçeklikten bağımsız değildir. Dolayısıyla ontolojiyle epistemoloji arasındaki kopuş yeniden teyellenerek insan dünyasının gerçekliği somutlaştırılabilir. Bu somutlaştırma işlemi, diyalektik kısma taşınacak olmakla birlikte bunun aracısının meşruiyet olduğu açıklıkla söylenebilir. Dolaysız bilinemeyen ancak dolaysız olarak sahip olduğumuz melekelerle bildiğimiz toplumsal gerçeklik, ancak meşru bir zeminde anlamlandırılmaktadır. İlerleyen kısımda meşruiyet kavramının anlamları soruşturularak gerçeklik ve meşruiyet ilişkisi için diyalektik bir patika oluşturulmuştur.

\subsection{Meşruiyet}

Gerçeklik, nesnel ve sosyal olarak iki farklı var oluş tarzı açısından felsefi literatürde yoğun bir şekilde tartış1lsa da sosyal bilimlerin nesnesi olan 'toplumsal gerçeklik' inşa edilmiş ya da kabul edilmiştir. Fakat bu kabul etme meşruiyet sorunsalını üretmektedir. Gerçek olanın kabul edilmesi ya da 'X Y koşullarında C sayılır' denmesi, içselleştirilmesi, belgelenmesi ya da statü ve işlev yüklenmesi onun meşruluğuna bağlıdır. Bu kısımda, 'meşruiyet gerçeklik için nasıl bir dayanak sağlamaktadır?' sorusu bağlamında meşruiyet kavramı tartışmaya açılmıştır.

Meşruiyet, "edebi anlamıyla bir sıfattır ve şer'i olan, şeraite uygun olan" demektir (Oktay 2003, 7). Meşruiyet, bir hukukiliğin, razı olunan bir belirlenimin sınırları içerisinde hareket etmektir. Latince'de legitimus olarak geçen kavram başlarda bir eylemi olumsuz değerlendirme ve ahlaka aykırılık anlamında; günümüzde ise, 'ilk sebep'e uygunluk anlamında kullanılmaktadır (Çetin 2003, 66). Türkçe Sözlük'te $(1998,1545)$ ise, “yasanın, dinin veya kamu vicdanının uygun bulduğu" şeklinde tanımlanır. İngilizce literatürde ise kavram ilk olarak "1356 yılında yayınlanan Mukaddes Roma İmparatorluğu'nun kayserinin seçim usulünü tanzim eden Altuni Ferman'da geçmektedir" (Schmitt 2016, XII). Literatürde kavramın diğer tanımları ise şöyledir:

Habermes'a göre meşruluk; “'bir siyasi düzenin tanınma ve kabul görme ehliyetidir. Selçuk, meşruluğu 'bir kurum, yasa ya da iktidarın arkasında, bilinen ve benimsenen (hukuka uygun) kurallara göre oluşmuş ve özgür rlzaya dayalı bir çoğunluğun varlı̆̆ı' olarak tanımlar. Poggi için meşruluk, 'otoriteye sorgusuz sualsiz bir sıradanlıkta ya da kişisel hesap çıkarlarıyla değil, doğru olduğuna inanıldı̆̆ için boyun eğilmesidir". Yayla'nın düşüncesinde meşruluk, 'yönetilenlerin, yönetenlere (siyasi iktidara) itaat edilmesi ve onun koyduğu kurallara uyulması gerektiğine olan inancl; toplumun yönetime rıza göstermesi, itaat etmesi durumunu' ifade eder. Dahl, meşruluğu bir sarnıç olarak görür: Belirli bir seviyede kaldiğı sürece siyasi iktidarl sağlam tutan ve onun istikrar içerisinde varlığını idame ettirmesini sağlayan, fakat belli bir seviyenin altına düşmeye başladiğ andan itibaren siyasal iktidarın varlığını ve devamını tehlikeye sokan bir sarnıç” (Coşkun 2009, 45).

Kavram genel olarak 'bir şeye uygun olan' anlamıyla ön plana çıkmaktadır. "Kelime yönünden yasallık, dine ve İlahi olana uygunluk, hukuka uygunluk gibi anlamlara gelmektedir" (Okumuş 2010, 13). Ancak 'uygun olduğu' şeyin uygunluğu belirsizdir. Başka bir deyişle toplumsal gerçekliğin inşası için dayanak olan meşruiyetin dayanağı yine kendisidir. Yani 'kendinereferanslıdır. Çünkü herhangi bir şeyin meşru kategorisi altında alınabilmesi için 'böyle olduğuna inanılmalıdır' ya da 'böyle kabul edilmelidir' yargısı benimsenmelidir (Searle 2005, 52). Nitekim kurumsal olguların bir gerçeklik olarak tanınmaları ancak onların kabul 
edilmeleriyle mümkündür. Genel olarak kavram, "toplumsal düzenin, rıza, sükunet ve uzlaşmayla geçerliliğinin kabul edilmesini" ifade eder (Okumuş 2010, 14). Kısaca meşruiyet, kendi meşru zemininin kaygan olduğu bir kavramdır.

Meşruiyet kavramı, Giddens'ın yapılaşma teorisinde önemli bir yer tutmaktadır. Kurallar ve kaynaklar olarak gördüğü yapılardan birini meşruiyet olarak değerlendirir ve meşruiyetin normatif bir düzenin ana öğesi olduğunu ve toplumda hukuk tarafindan temsil edildiğini belirtir. Meşruiyet, "haklar ve yükümlülükler şeklinde somutlaşan değer standartları üzerinde özel bir mutabakatı anlatmaz; belirli bir toplumdaki değer standartlarıyla özel çıkarlar arasındaki etkileşimi daha net olarak değerlendirmemize yardımcı olur" (Giddens 2005, 254). Giddens, toplumsal gerçekliğin çeşitli meşrulaştırma düzenleri tarafından yapılaştığını düşünür. "Meşrulaştırma düzenleri, ancak en azından bir kolektivite veya toplumun belirli oranda üyesinin eylemlerinin yapısal koşulu haline geldiklerinde bağlayıcı bir güce sahip olabilir" (Giddens 2005, 255). Başka bir deyişle meşruiyet Giddens için kabule dayanır. "Meşruiyet, ya bir takım sosyal zorlamalar ya da eylemin arzulanan modeli olarak bir sosyal düzen için aktörlerin uyumunu belirtir" (Johnson et al. 2006, 55). Bu normatifliği sayesinde meşruiyet, yaptırım gücü elde eder. Dolayısıyla meşrulaştırma prosedürleri yaptırım gücüne sahiptirler. "Meşruiyetin temel fonksiyonları; zorlama ve baskı kapasitesi, iktidarın haklılığına olan inancın beslenmesi, siyasal iktidarın toplumun bütününün ve çıkarlarının temsilcisi olduğuna inancın güçlendirilmesidir" (Çetin 2003, 68). Meşruiyet bu anlamda eylemlere açıklanabilirlik/ gerekçelendirme sunar. Elbette bir davranışın meşruluğunun sağlanması süreci farklı meşrulaştırıcı araçlarla gerçekleştirilmektedir. Her ne kadar meşruiyet tartışmaları siyasal alanında yapılmış olsa da kurumsal olguların varlığı onların meşruiyetiyle ancak anlamlandırılabilir. Meşruiyet söz konusu olmadığında bir kurum inşası olanaksızdır.

Giddens, meşruiyetten yapıyı anlamaktadır. "Yapılar, sosyal sistemlerin kurumsal eklemlenişinde yer alan kural ve kaynak setleri olarak yani: anlamlandırma, egemenlik, meşrulaştırma yapıları olarak tanımlanabilir" (Giddens 2005, 73). Meşruiyet, yapıların insanlar tarafından anlamlı hale getirilerek bir alışkanlık zincirinin içine katılması anlamını taşımaktadır. Kısacası, Giddens için meşruiyet yapıların anlamlandırılmasının aracıdır. "Anlamlandırma yapıları semantik kurallar olarak, meşrulaştırma yapıları ahlak kuralları sistemi olarak, egemenlik yapıları da kaynaklar sistemi olarak düşünülebilir" (Giddens 2005, 76). Meşruiyet, eylemleri belirlemektedir. Sosyal sistemlerin yapısal bir özelliği olarak egemenliğin somut sosyal hayat koşullarında her zaman anlamlandırma ve meşrulaştırmayla ilişki içinde işlediğini vurgular (Giddens 2005, 87). Giddens için kurallar ve kaynaklar olarak tanımladığı yapılaşma, meşrulaştırma aracılığıyla bir araya gelir (Giddens 2005, 87). Meşruiyet, yapılaşma sürecinin katalizörüdür. Bu katalizör, hukuksal kurumlarda somutlaşır. "Meşrulaştırma yapıları ile ilgili aktörlerin etkileşimini normlar aracıllı̆ı̆yla yaptırımlar biçiminde sağlar" (Giddens 2005, 88). Dolayısıyla meşruiyet, bir kurumu anlamak ve gerçekliğine onay vermek için kullanılan bir kavramdir.

İktidarın onanmasını sağlayan meşruiyet, böylece onu yeniden üretir. Özellikle Weber'in geleneksel, karizmatik ve yasal otorite tipolojisi bunun bir göstergesidir. Weber (1995) için meşruiyet siyasal bağlamda düşünülmüş olsa da eylemlerin gerekçesi anlamına gelmektedir. Çünkü meşruiyet, otorite türlerinin toplumsal failler tarafından benimsenmesi, içselleştirilmesi ve kabul edilmesinin koşul ve kurallarını sağlar (Marshall 1999, 495). Başka bir deyişle statü ve işlev yükleme ya da içselleştirme ve nesnelleştirme süreçlerinin varlığı ancak meşruiyet zemininde anlam kazanmaktadır. Özellikle devletin ve devlet organlarının icraatlarının dayanakları, meşruiyetin varlık alanlarını oluşturmuştur. Örneğin, parlamenter demokraside meşruiyet, yasal sınırlara riayetle eş tutulmaktadır (Scmhitt 2016, 11). Dolayısıyla parlamenter sistemi meşrulaştıran prosedürler 'yasa'dır. Başka bir deyişle böyle bir sistemde meşruiyet, yaygın kabul 
edilen bir takım yasaların varlığına karşılık gelmektedir. Ancak bir yasanın varlığı ile meşruluğunu kazanan parlamenter demokrasi örneğinde olduğu gibi 'bu yasanın varllğının meşruiyeti nedir?' sorusu boşlukta kalmaktadır. Çünkü birçok insanın herhangi bir şeyi kabul etmesinin meşruiyeti bütünüyle ya müphem ya da metafizikseldir. Bu bağlamda meşruiyet, 'bir davranışı haklılandırdı̆̆ı' gibi kendisini de haklılandırılmaktadır.

Gündelik hayatın 'katlanılmaya değer' hale gelebilmesi, üretilen anlamların benimsenmesiyle doğru orantılıdır. Meşruiyet, gündelik hayatın anlamlandırılması ve yapılaştırılması için elzemdir. Toplumsal etkinliğin icrası ve bu icraların içselleştirilmeleri yahut bu icralara statü ve işlev yüklenmesi meşruiyet aracılığıyla sağlanır. Başka bir deyişle toplumsal gerçeklik, meşrulaştırma prosedürleri aracıllğıyla yeniden üretilir. Bu prosedürler ve bu prosedürlerin icrasından sorumlu ajanlar çeşitli yol ve yöntemler kullanabilirler: "Göz dağı teknikleri, rasyonel ya da irrasyonel propaganda, mistifikasyon, prestij sembollerinin kullanımı" (Berger \& Luckmann 2008, 128). Böylece bir 'düzen'den bahsedilebilir:

\section{"Meşrulaştırma, kurumsal düzenin nesnelleşmiş anlamlarına bilişsel bir geçerlilik atfetmek suretiyle bu düzeni 'izah eder'. Meşrulaştırma, kurumsal düzenin pratik buyruklarına normatif bir itibar kazandırmak suretiyle bu düzeni haklılaştırır” (Berger \& Luckmann 2008, 137).}

İnsan, meşrulaştırma sayesinde çözümsüz bir dehşetten kurtarılır. Ancak bu kurtuluş görüldüğü gibi döngüseldir. Meşrulaştıran araçların meşruiyeti ya da meşruiyetin meşruiyeti daima müphem kalır. Bu soyutluk ancak kavramın gerçeklikle olan diyalektiğinin açık bir şekilde ifade edilmesiyle somutlaştırılabilir. İlerleyen kısımlarda bu ilişki görünür hale getirilmiştir.

\section{Diyalektik Düşünme}

Diyalektik düşünmede meşruiyetin toplumsal gerçekliği nasıl etkide bulunduğu ve gerçekliğin meşruiyeti nasıl yeniden ürettiği tartışmaya açılmıştır. Ilk olarak meşruiyetin meşruluğu tartış1lıp toplumsal gerçeklikle olan ilişkisi ortaya çıkarılmıştır. İkinci olarak gerçekliğin meşrulaştırıcı prosedürleri nasıl haklılandırdığı ifade edilmiştir. Böyle bir düşünce sürecini izlemek bir nevi başlangıç noktasına dönüş yolculuğuna çıkmaktır. Dolayısıyla toplumsal gerçekliğin meşruiyeti üzerine düşünmenin meşruiyeti sağlanmış olur. Buna ek olarak gerçekliğin nesnel gerçeklik açısından bir meşruiyete ihtiyaç duymadığı oysa kurumsal/sosyal gerçekliğin meşruiyete ihtiyaç duyduğu belirtilmiştir.

\section{1. Meşruiyetin Meşruiyeti}

Meşruiyet, toplumsal gerçekliğin anlamlandırıcı ana öğesidir. Meşruiyet, toplumsal etkinliğin ve bireylerin davranışlarının dayanağını oluşturmaktadır. Ancak kendinden-referanslı olması nedeniyle kendi meşruiyeti müphemdir. Bu kısım altında 'meşruiyetin meşruluğu nasıl sağlanır?' sorusuna dört unsur belirlenerek cevap verilmiştir: Ahlak, din, yasa ve tarih. Ancak, en nihayetinde, bu unsurların meşruiyet için dayanak teşkil etmeleri bütünüyle 'kabule dayalı' olduğu da belirtilmiştir. Dolayısıyla meşruiyet, toplumsal gerçekliği ancak onanma düzeyinde meşrulaştırabilir daha fazlası değil.

Ahlak, davranışları belirleyen ana ilkelerden oluşması nedeniyle meşruluğa duyulan toplumsal ihtiyacın ana merkezini oluşturur. Özellikle 'olması gereken'e dönük beklenti taşıması nedeniyle toplumsal etkinliğin ilkeye uygunluğunu sağlamaktadır (Durkheim 2010). Bu çerçevede meşruiyet, ahlaki bir ilkeye referans verdiği zaman toplumsal etkinliklerin anlamlandırılması sağlar (Giddens 2013). Fakat meşruiyetin kendine-referanslı oluşu nedeniyle bir ahlaki ilke veya erdeme dayanması tam olarak beklenemez. Ancak yine de 'herhangi bir pratiğin meşru olmasının gerekçesi olarak ahlaki ilkeler gösterilebilir. Bu yalpalayan düşüncenin gerekçesi ise evrensel/genel geçer ahlaki ilkelerin neler olduğu konusundaki tartışmalar yatmaktadır. 
Örneğin, Kant'ın bahsettiği anlamda 'öyle bir ilkeye uy ki herkes ona uysun' önermesinin evrenselliği tartışmalıdır. İnsanlardan akılları sayesinde bir ilkeye 'saygı' duymalarının beklenmesi bir beklenti olarak mümkün ancak realitede karşılığını bulmak imkansızdır. Özetle, "meşruluk sorununun temelinde 'olması gerekenle' ilgili bir alana ilişkin olduğu" söylenebilir (Gürbüz 2004, 7). Ancak bu alanın onanmasını sağlayan meşruiyet, meşrulaştırılmaya ihtiyaç duymamaktadır. Dolayısıyla ahlak, meşruiyet için başvurulan dayanaklardan biri ancak her daim koşulu değildir.

Meşruiyetin kendisine sıklıkla dayanak olarak gösterdiği diğer bir olgu ise 'din'dir. Gündelik hayatta birçok eylem dine dayandığı müddetçe meşruiyetini elde eder. "Devlet, sultan veya yönetici, meşruiyetini temelden dinden sağladığı gibi, muhalif cephe veya cepheler de meşruiyetlerini dinden elde etmek zorundadırlar" (Okumuş 2010, 32). Özellikle teodise ve sosyodise bağlamında din meşru bir dayanak olarak kabul edilmektedir.

“Tarihsel ve toplumsal olarak bakıldığında görülür ki dini meşrulaş̧tırım
aracıllı̆̆ıla savaşlar 'kutsal savaşlar' olarak haklılaştırllır; sorumluluk
veya mükellefiyetler, 'kutsal görevler' olarak geçerlilik elde eder;
üstünlük, güç, baskı veya egemenlik, 'Ilahi Krallık' olarak haklılık
payesine kavuşur” (Okumuş, 2010,36).

Meşruiyet dine dayanarak eylemler için sunduğu gerekçelerin onanmasını sağlar. "Weber'in ortaya koyduğu gibi din toplumda gücün kullanımını haklı gösterir, açıklar ve rasyonalize eder" (Okumuş 2010, 38). Gerçekliğin üreticisi olarak meşruiyet, toplumsal yasaların üretiminin muhafazasını yapar. Böylece toplumsal gerçekliği ebedi gerçekliğe bağlar (Berger 1993, 65). Bu anlamda meşruiyet, kendisini dine dayandırdığı sürece herhangi bir davranışın onanmasını sağlar. Ancak din, meşruiyetin dayanaklarından biri olsa da 'hangi din' sorusu meşruiyetin dayanağını olarak tek başına kullanılmasının önüne geçer.

Meşruiyetin, bir diğer dayanağı ise 'yasa'dır. "Nomos, doğa anlamına, doğaya -ya da en azından yapılması gerekene- uygun davranış anlamına gelir" (Foucault 2012, 151). Genel olarak yasa tarihsel bir evrenin onadığ 1 genel kabullere/kurallara işaret eder. Ancak bu kabuller daha çok yasaklar ekseninde ifade edilir. "Yasallık sistemi, yasa sistemi esas olarak şeyleri tam da yasaklandıkları ölçüde belirleme işlevi taşır" (Foucault 2013, 45). Yasa dünyanın kabul edilmiş bir kural etrafında yorumlanmasını içerir. Ayrıca yasa belli bir ilke etrafında toplumsal için inisiyatif alabilecekleri bağlayan bir kuraldır. Alınan her inisiyatifin meşru zeminini yasa sağlamaktadır. Başka bir deyişle mevzuata uygunluk meşruiyet için bir dayanak teşkil etmektedir. Ancak 'hangi mevzuat? kimin yasası? hangi yasa?' soruları bu dayanağın tek başına yeterliliğini sarsmaktadır.

Meşruiyetin bir diğer dayanağ 1 da 'tarih'tir. Herhangi bir toplumsal eylemin meşruiyeti onun tarihsel olarak desteklenmesiyle doğru orantılıdır. Tarih, bir eylemin onanması için yeterli argümanlar sunar. Örneğin Weber'in geleneksel otoritesinin meşrulaştırıcısı önemli oranda tarihtir. Aynı şekilde Durkheim'ın dinin ilksel formuna başvurması tarihin meşrulaştırıcı gücünü gösterir. Nitekim Durkheim $(2009,23)$, "gerçekte tarih, dinlere uygulanabilecek yegâne açıklamalı analiz metodudur" diyerek, tarihsel kökene yönelmeyi tavsiye eder. Ayrıca tarih, kurumsal olgular için anlam üretimini sağlar. "Çoğu yasallaştırmalar netice itibariyle preteorik (teoriöncesi) bir niteliğe sahiptir" (Berger 1993, 62). Dolayısıyla toplumsal gerçeklik denetimler deposu olan tarih sayesinde meşrulaştırılır. Bu meşrulaştırmanın mekaniği ise şöyledir:

"İster Hellen olsun, ister barbar olsun, bütün uluslar şu aynı kanıya sahiptir: Bütün diğer uluslardan önce o ulus, insan yaşaminin rahatllklarını icat etmiştir ve onun tarihi dünyaların ta başlangıcına kadar geri gider" (Vico 2007, 91). 
Bu işlem mevcut toplumsal gerçekliğin arkaikliğini öne çıkararak onun kabul edilmesini sağlar. Böylece tarih, "çevremizi saran ve bizi işgal eden bugünün sorunları adına geçmiş zamanların sürekli sorgulanma"mıza imkan sunar (Braduel 2008, 9). Dolayısıyla inşa edilmiş bir tarih, en büyük meşrulaştırıcı dayanaktır. Örneğin, tarihsel kozmogoniler gerçekliği haklılandırmak veya gerekçelendirmek için vazgeçilmez olanaklar sunar. "Tarihçi, metnini oluştururken yaptığ1 seçimler ve içinde bulunduğu yaklaşımlarla, arşivlerin sessiz metinlerinden kopardığ 1 sözlere o güne kadar yüklenmeyen anlamlar yükler" (Chartier 1998, 11). Böylece meşruiyetin güçlü bir dayanağı olarak tarih, bir eylemin referansı olabilir. Ancak tarih zaferlerle dolu olduğu kadar utançlarla da doludur. Dolayısıyla tarih 'tek başına' bir dayanak olarak görülemez.

Belirtilen bu dört referans kaynağı aslında bir eylemi meşrulaştırmak için meşruiyetin başvurduğu araçlardır. Bu dört ilke -tek başlarına yetersiz de olsa- meşruiyetin toplumsal gerçekliği inşa etmek için bir zemin sundukları gösterilmiştir. Sonraki kısımda ise nitelikleri ve anlamları ortaya çıkarılan bu iki kavramın birbirlerini nasıl somutlaştırdığı örneklenmiştir.

\subsection{Gerçeklik ve Meşruiyet Diyalektiği}

Toplumsal gerçekliğin inşası ya da sosyal gerçekliğin anlamlandırılması için meşru bir zemine ihtiyaç duyulmaktadır. Toplumsal gerçeklik için meşruiyet, 'kabul etme'yi, 'gerekçe sunma'yı ve 'haklılandırma' yı sağlar. Başka bir deyişle meşruiyetin meşru bir zemininin sorunsallığı ve kavramın kendinden-referanslı olması nedeniyle en nihayetinde toplumsal gerçekliğin kabul edilmiş, gerekçelendirilmiş ve haklılandırılmış bir gerçeklik olduğu söylenebilir. Dolayısıyla meşruiyetle toplumsal gerçeklik birbirlerini karşıllklı olarak yeniden üretmektedirler. Ancak bu yeniden üretimde meşruiyet, toplumsal gerçekliğin inşasının zeminini kurmaktadır. $\mathrm{Bu}$ bağlamda meşruiyetin, "bireylerin davranışlarına ve algılarına aracılık etmesinde rağmen, kolektif bir süreç" olduğu belirtilmelidir (Johnson et al. 2006, 57). Her ne kadar meşruiyet, toplumsal gerçeklik için zemin kursa da onun tarafından somutlaştırılır. Bu kısımda iki kavramsallaştırma arasındaki diyalektik bağlantı 'bilime yaklaşımlar' örnek gösterilerek gösterilmeye çalışılmıştır.

Yukarıda yürütülen tartışmanın somut bir örneği olarak bilimin toplumsal gerçekliğinin inşasında meşruiyetin rolüne bakmak yeterli olabilir. Özellikle beşeri bilimlerle doğa bilimleri arasında yaşanan çekişmede bu oldukça belirgindir. Nomotetik bilim anlayışıyla ideografik bilim anlayışlarının çatışması meşruiyet kavgasına işaret etmektedir (Çiftçi 2016). Pozitivistler gerçekliğe uygun veri toplama araçlarını üretebileceklerini düşünür ve pozitivist nomolojik bilim anlayışı "testleri, kuramların deneyimde olası sınanmasıyla özdeşleştirir"ler (Habermas 1998, 53). Başka bir deyişle "gözlem, gözlem ifadeleri ve gözlemlenebilirlikle ilgili tartışmaların çoğu pozitivist mirasımızdan kaynaklanır. Pozitivizmden önce gözlem merkezi bir yere sahip değildi" (Hacking 2016, 208). Bu bağlamda "pozitivizm görmenin inanmak olduğu görüşünden doğar. ... Pozitivist elektronlara inanılamayacağını çünkü onların görülemeyeceğini söylemeye devam eder. (Hacking 2016, 88). Bu pozitivist iddia -özdeşleştirme- sadece varsayımsal olup totolojik bir meşrulukla ancak varlı̆̆ını devam ettirmektedir. Nitekim Kuhn'un bilim tarihini devrimler ve kopuşlar olarak yorumlaması da değişen bu meşruiyet anlayışıyla örtüşmektedir. Nitekim Ferrais $(2014,39)$ şöyle der:

"Pozitivizme geri dönüs yoktur. Aksine, bilimi yücelten pozitivizme karşı
ve onu çıkarlar arasındaki mücadeleye indirgeyen postmodernizme karşı
ortak akıl dünyası, ahlaki değerler ve görüsler ile genel olarak bilgi
dünyası arasında bir köprü olarak bir felsefenin yeniden doğuşunu
öneriyorum”.

Pozitivizmin karşıtı olarak ideografik bilim anlayışı meşruiyetini, hermeneutik veya sembollerin analiziyle sağlamaktadır (Sunar 2008). Eyleyen öznenin öz-anlayışı hakkında teknik araçlarla (istatistiksel ölçekler gibi) bir aydınlanmaya ulaşılamayacağı gibi bu araçların yaygın kullanımı 
ile bazen gerçeklik de 1skalanabilir. Bu iki alan bir çatallanma eğiliminde olup aralarındaki çatışma sürekli bir yarışa yol açmaktadır (Wallerstein 2003). Ancak ikisi de gerçekliği yakalamaya çalıştıklarını ve sundukları verilerin gerçekliği temsil ettiğini öne sürmektedirler. Her iki yaklaşımın dayanağı ise meşruiyet mefhumudur.

Doğa bilimin iddia ettiği şeyin kesin ve doğru olduğu inancı, meşruiyetini kendi varoluş yasalarından ve bu yasaların tarihselliğinden almaktadır. "Doğa bilimleri, gerçekliğin dünyaya içkin olan özellikleri herhangi bir gözlemciden bağımsız olarak var olduğu şeklinde tasvir etmektedirler" (Searle 2016, 35). Naturalist bir bakışla tanımlanan doğa çeşitli fizik kanunları, kimyasal tepkimeler ve bunların keşfiyle açıklanmaya çalışılır. Ancak bu yasalar ve işleyiş biçimleri tarihsel olarak dönüşmektedir. Nitekim Hacking'in Şansın Terbiye Edilişi (2005) adlı metni bu dönüşü istatistik biliminin tarihsel evrimden hareketle göstermektedir.

"Bana göre Peirce’ın önemi, modern felsefenin demirbaşlarından biri
yapan onun dilidir. Bence önemli biridir, çünkü bizim şansa dayalı bir
evrende yaşadığımızı açıç̧a ifade eden ilk insandır. Bu şans hem
belirlenimsizdir; hem de olasılık yasaları yüzünden doğanın düzenli
yasalarla yönetildiğine olan yanlış inancımızın kaynağıdır” (Hacking
2016, 86).

Toplumsal bir gerçeklik olarak bilim, meşruiyetini kendinden alan disiplinler topluluğudur. Ayrıca bu meşruiyetin dayanakları ilkelere göre hareket etmesinden de gelmektedir. Bilimsel yaklaşımın temel ilkeleri (evrensellik, kesinlik, test edilebilirlik vd.) bu meşru dayanaklara işaret etmektedir. Bu ilkeli davranışı yasa ya da ahlaki ilkelerle birleşmektedir. Aynı zamanda doğa bilimleri bir dünya kavramsallaştırması inşa ettiğinden kendisini meşrulaştırıcı bir araç haline de dönüştürmektedir. Bilim, kendi meşru temelini sosyal bilimlere de tevarüs ettirmiştir. Nitekim sosyal bilimlerde özellikle pozitivist bilgi anlayışıyla gerçeklik alanının sınırları çizilmiş, oyun olarak görülen dünyanın işleyiş kurallarının belirlenmesine dönük çalışmalar yapılmış, gerçeklik duyu izlenimlerine indirgenmiş, metafizik dışlanmış bir şekilde sosyal alanın meşruiyet zemini belirlenmiştir (Giddens 2008, 145). Bilim, meşruiyetini, gerçekliğin tasvirini en iyi şekilde yaptığı iddiasını kabul ettirmesiyle elde etmektedir.

Doğa bilimlerinin sosyal bilimlere tevarüsü neticesinde özellikle pozitivist yaklaşımda toplumsal gerçekliğin yasa-benzeri bir olgusallığa sahip olduğu düşünülmekte ve şeyler-arası ilişkiler bu yasanın bulunmasıyla açıklanabileceği ifade edilmektedir. Toplumsal gerçekliğin yasa-benzeri olduğu iddiası meşru bir zemin talebini üretmektedir. Nitekim böyle bir yaklaşımın karşı kutbu bu zemin talebini yadsımak için devasa bir külliyat oluşturmuştur. Böylelikle bilimin toplumsal gerçekliğinin temeli (hem doğa hem sosyal bilim açısından) meşruiyetle doğrudan ilişkilidir. Meşruiyeti, onun hem harcı hem de zeminidir. Dolayısıyla toplumsal gerçeklik alanı olan bilim, meşruiyetle anlamlandırılmaktadır. Anlamlandırıldıkça da meşrulaştırıcı presedürlerinin güncellenmesini sağlamaktadır. Bir örnek olarak seçilen doğa bilimine yaklaşımdan hareketle meşruiyet ile toplumsal gerçeklik arasındaki ilişki kaçınılmaz olarak döngüseldir.

\section{Sonuç}

Gerçeklik, Hacking'e göre 'müdahale etme'yle görünür olsa da sosyal inşacı bakış açısına göre semboller aracılığıyla inşa edilmektedir. Kurumsal/sosyal gerçekliğ in fiziksel bir varlığı zorunlu kıldığ 1 düşüncesi (her ne kadar Ferraris 'belgeleme' kuralı ile bir varlığın üretiminden bahsetse de aslında olan şey göstergenin sınırları dahilindedir) doğruyu yansıtmaz. Nitekim sanal paraların varlığı, cisimsel bir varlığı gerektirmemektedir. Dolayısıyla toplumsal gerçekliğin inşası fiziksel niteliklere de gömülü olmakla birlikte oldukça semboliktir. $\mathrm{Bu}$ anlamda meşruiyet, toplumsal gerçekliğin inşasında ya düzenleyici bir görünüm kazanır ya da nesnenin varlı̆̆ının 
şartlarını ifade eder. 'Meclis yasa yapar' gibi kuralcı ya da 'vekiller el kaldırarak oy kullanır' gibi düzenleyici kurallar aracılığıyla toplumsal/kurumsal gerçeklik görünür olur. Tüm bu tartışmalardan hareketle meşruiyetle toplumsal gerçeklik arasındaki ilişki 'yapılaşma' süreciyle açıklanabilir. Örneğin, “'simgesel' kavramı her şeyden önce gerçeklik kavrayışımızın dolaysız olmadığını dile getirmek için vardır" diyen Ricouer'ün $(2006,23)$ yorumu, gerçeklikle onun ifadesi arasında bir boşluğun olduğunu dile getirmektedir. Gerçeklik bir araciyla bilinebiliyorsa, gerçekliğin kurucusunun meşruiyet olduğu aşikardır. Çünkü, "gerçek olanı imleyerek söylüyoruz; bu anlamda yorumluyoruz onu" (Ricouer 2006, 32). Dolayısıyla biz gerçekliği ifadeler üzerinden yani dil aracılığıyla bilebiliriz. Başka bir deyişle herhangi bir şeyi anlamlandırmak ancak meşru bir araç varsa mümkündür.

Toplumsal gerçeklik ancak meşru ise inşa edilebilmektedir. Dolayısıyla meşruiyetin toplumsal gerçekliğin zeminini inşa ettiği söylenebilir. Fakat meşruiyet kendinden-referanslı bir kavram olduğu için toplumsal gerçekliğe sunmuş olduğu bu zemin bütünüyle kurgusal olduğu da açık bir şekilde ifade edilmelidir. Böyle bir toplumsal gerçekliğin hakikatle olan ilişkisi daima mesafeli kalacaktır. Toplumsal gerçekliğin hakikate mesafeli bir gerçeklik olduğunun ortaya çıkması sonucunda gerçeklik üzerine yapılan yorumlar onu rölativizm ejderhasının menüsü olmaya zorlar. Ancak toplumsal gerçekliğin başından beri varsayımsal bir gerçeklik olduğunu bilmek rölativizmin aksine, daha güçlü dayanaklar üretmek için insanı zorlayacak ve yeni arayışlara kapı aralayacaktır. Zamanında, Marx'ın din için yaptığı 'gemi benzetmesi'nin aslında toplumsal gerçeklik için de geçerli olduğunu belirtebiliriz.

\section{KAYNAKÇA}

Bauman Z. (2000). Siyaset Arayışı. Çev. T. Birkan. İstanbul 2000.

Berger P. \& Luckmann T. (2008). Gerçekliğin Sosyal İnşası. Çev. V. Saygııı̈ı̈ğütle. İstanbul 2008.

Berger P. (1993). Dinin Sosyal Gerçekliği. Çev. A. Coşkun. İstanbul 1993.

Bhaskar R. (2005). Gerçekliği Geri Kazanmak: Çağdaş Felsefeye Eleştirel Bir Giriş. Çev. B. Sumer Aydaş. Ankara 2005.

Bhaskar R. (2017). Insan Bilimlerinin Felsefi Eleştirisi: Naturalizmin Olanaklılı̆̆ı. Çev. V. Saygılı Öğütle. Ankara 2017.

Braduel F (2008). Akdeniz: Tarih, Mekan, Insanlar ve Mirası. Çev. N. Erkurt \& A. Derman. İstanbul 2008.

Burr V. (2012). Sosyal İnşacıllk. Çev. S. Arkonanç. Ankara 2012.

Chalmers A. (2010). Bilim Dedikleri. Çev. H. Arslan. İstanbul 2010.

Chartier R. (1998). Yeniden Geçmiş. Çev. L. Arslan. Ankara 1998.

Coşkun V. (2009). Ulus devletin Dönüşümü ve Meşruluk Sorunu. Ankara 2009.

Çetin H. (2003) "Siyasetin Evrensel Sorunu: İktidarın Meşrutiyeti - Meşruiyetin İktidarı". Ankara Üniversitesi Siyasal Bilgiler Fakültesi Dergisi 58/3 (2003) 62-88.

Çiftçi A. (2016). Nasıl Bir Sosyal Bilim. Ankara 2016.

Durkheim E. (2009). Dini Hayatın İlk Biçimleri. Çev. İ. Er. İstanbul 2009.

Durkheim E. (2010). Sosyoloji Dersleri. Çev. A. Berktay. İstanbul 2010.

Ferraris M. (2013). "Perspectives of Documentality". Eds. C. Barbero, M. Ferraris \& A. Voltolini, From Fictionalism to Realism. Cambridge 2013.

Ferraris M. (2014). Manifesto of New Realism. Trans. S. de Sanctis. Albany 2014.

Foucault M. (2012). Bilme İstenci Üzerine Dersler. Çev. K. Eksen \& F. Taylan. İstanbul 2012.

Foucault M. (2013). Güvenlik, Toprak, Nüfus. Çev. F. Taylan. İstanbul 2013.

Giddens A. (2005). Sosyal Teorinin Temel Problemleri. Çev. Ü. Tatlıcan. İstanbul 2005.

Giddens A. (2008). Siyaset, Sosyoloji ve Toplumsal Teori. Çev. T. Birkan. İstanbul 2008. 
Giddens A. (2013). Sosyolojik Yöntemin Yeni Kuralları. Çev. Ü. Tatlıcan \& B. Balkız. Ankara 2013.

Gürbüz A. (2004). Hukuk ve Meşruluk. İstanbul 2004.

Habermas J. (1988). Legitimation Crisis. Trans. T. McCarthy. Cambridge 1988.

Habermas J. (1998). Sosyal Bilimlerin Mantığı Üzerine. Çev. M. Tüzel. İstanbul 1998.

Hacking I. (2005). Şansın Terbiye Edilişi. Çev. M. Moralı. İstanbul 2005.

Hacking I. (2016). Temsil ve Müdahale. Çev. O. A. Altık. İstanbul 2016.

Harman G. (2015). "Fear of Reality: On Realism and Infra-Realism". The Monist 98 (2015) 126-144. Doi: 10.1093/monist/onv001

Harman G. (2016). Immaterialism: Objects and Social Theory. Cambridge 2016.

Hegel G. W. F. (1996) Ana Hatlarla Felsefi Bilimler Ansiklopedisi I, Mantık Bilimi. Çev. A. Yardımlı. İstanbul 1996.

Heywood A. (2017). Siyaset Teorisine Giriş. Çev. H. M. Köse. İstanbul 2017.

Johnson C., Dowd T. \& Ridgeway C. (2006). "Legitimacy as a Social Processs". Annual Review Sociology 32 (2006) 53-78.

Marshall G. (1999). Sosyoloji Sözlüğ̈̈. Çev. O. Akınhay \& D. Kömürcü. İstanbul 1999.

Oktay C. (2003). Siyaset Bilimi İncelemeleri. İstanbul 2003.

Okumuş E. (2010). Meşruluğun Toplumsal Gerçekliği. İstanbul 2010.

Rawls J. (2007). Siyasal Liberalizm. Çev. M. F. Bilgen. İstanbul 2007.

Ricoeur P. (2006). Yoruma Dair: Freud ve Felsefe. Çev. N. Alpay. İstanbul 2006.

Schmitt C. (2016). Kanunilik ve Meşruiyet. Çev. M. C. Ozansu. İstanbul 2016.

Schutz A. (1962). Collected Papers: The Problem of Social Reality. Ed. M. Natanson. Netherlands 1962.

Searle J. R. (2005). Toplumsal Gerçekliğin İnşası. Çev. M. Macit \& F. Özpilavcı. İstanbul 2005.

Searle J. R. (2015). Zihin, Dil ve Toplum: Gerçek Dünyada Felsefe. Çev. A. Tural. İstanbul 2015.

Searle J. R. (2016). Bilinç ve Dil. Çev. M. Macit \& C. Özpilavcı. İstanbul 2016.

Sunar I. (2008). Düşün ve Toplum. İstanbul 2008.

Trigg R. (2005). Sosyal Bilimleri Anlamak. Çev. B. Sümer \& F. Ülgüt. İstanbul 2005.

Türkçe Sözlük (1998). Haz. İ. Parlatır, N. Gözaydın \& H. Zülfikar. Ankara 1998.

Vico G. (2007). Yeni Bilim. Çev. S. Önal Ankara 2007.

Wachterhauser B. R. (2002). "Söylediğimiz Şey Olmamız Gerekir mi? İnsan Bilimlerinde Hakikat Üzerine Gadamer”. Hermeneutik ve Hümaniter Disiplinler (2012) 127-14. İstanbul.

Bourdieu P. \& Wacquant L. (2003). Düşünümsel Bir Antropoloji İçin Cevaplar. Çev. N. Ökten. İstanbul 2003.

Wallerstein I. (2003). Yeni Bir Sosyal Bilim İçin. Çev. E. Abadoğlu. İstanbul 2003.

Weber M. (1995). Toplumsal ve Ekonomik Örgütlenme Kuramı. Çev. Ö. Ozankaya. Ankara 1995.

Woolgar S. (1999). Bilim İdesi Üzerinde Sosyolojik Bir Deneme. Çev. H. Arslan. İstanbul 1999. 
